\title{
Work Motivation on Lecturer Achievement: Job Satisfaction as Mediating Variables
}

\author{
Titin Dunggio \\ Sekolah Tinggi Ilmu Adminitrasi (STIA) Bina Gorontalo, Indonesia \\ Email Address: \\ titindunggio0901@gmail.com
}

\begin{abstract}
This study focused on seeing the effect of mediation of job satisfaction between competency and motivation towards lecturer achievement and also partially tested both variables. The object of this study was lecturers at universities in Gorontalo, with 100 respondents by spreading quisioner online. This study also uses structural equation technique with data analysis using SEM-PLS. The results showed that competency variables have a positive and significant influence both partially and mediation of job satisfaction to lecturer achievement. This research can be a reference for universities in looking at competency and motivation relationships through mediating of job satisfaction towards lecturer awards to be able to take the right policies. This research in the design is static, the model that we developed based on empirical studies and testing that is only limited to putting together a simple relationship related to competency variables and motivation as variables that can affect lecturer achievement by mediation of job satisfaction variables.
\end{abstract}

Keyword: Competence; motivation; job satisfaction; lecturer achievement.

\begin{abstract}
Abstrak: Penelitian ini difokuskan untuk melihat pengaruh mediasi kepuasan kerja antara kompetensi dan motivasi terhadap prestasi kerja dosen serta menguji secara parsial kedua variabel tersebut. Objek penelitian ini adalah para dosen pada perguruan tinggi di Gorontalo, dengan 100 responden dengan menyebarkan kuisioner secara online. Penelitian ini juga menggunakan teknik persamaan struktural dengan analisis data menggunakan SEM-PLS. Hasil penelitian menunjukkan bahwa variabel kompetensi berpengaruh positif dan signifikan baik secara parsial maupun mediasi kepuasan kerja terhadap prestasi kerja dosen. Penelitian ini dapat menjadi acuan bagi perguruan tinggi dalam melihat hubungan kompetensi dan motivasi melalui mediasi kepuasan kerja terhadap penghargaan dosen untuk dapat mengambil kebijakan yang tepat. Penelitian ini di desain bersifat statis, model yang kami kembangkan berdasarkan studi empiris dan pengujian yang hanya sebatas menyusun hubungan sederhana terkait variabel kompetensi dan motivasi sebagai variabel yang dapat mempengaruhi prestasi dosen dengan mediasi variabel kepuasan kerja.
\end{abstract}

Kata Kunci: Kompetensi; motivasi; kepuasan kerja; prestasi dosen.

\section{INTRODUCTION}

The process of improving the quality of human resources is the main sarsaran of national development as well as the global competition in all fields is getting tighter (Hanafi and Yohana, 2017), because the era of globalization is a time full of challenges, so that it 
can turn these challenges into opportunities, it needs adequate capabilities from every actor of the organization and the company shown by the effectiveness of better work (Suprianto et al., 2019), and reliable human resources is a very urgent need to be fulfilled, if personnel in the organization are not able to answer the challenge, then the challenge that arises is a serious threat that must be worked out (Pramukti, 2019).

The importance role of human resource development in an organization in order to exist in a climate of free competition without limits, the role of management is not only the responsibility of employees in this case are lecturers, but is the responsibility of leaders in an organization or institution of higher education. Management of human resources management must of course be carried out by professional leaders. So, every lecturer who works naturally has various shortcomings and limitations, both in physical ability, thinking power, technological mastery and limited time (Pramukti et al., 2019). While the activities carried out by lecturers are increasing, thus encouraging the lecturer to cooperate with others and to meet the demands of expectations and expectations, one of which is to enter the collaborative world. Furthermore (Suprianto et al., 2019) an organization in human resources is a determinant element in an organization or agency. Furthermore, human resource management becomes important because human beings are an integral part of the organization and in its development raises the quality of many aspects and demands that must be achieved.

(Suharto, 2012) Decreased lecturer performance can cause uncomfortable feelings for lecturers. Thus, causing helplessness and worry. In addition, the lack of confidence in his own abilities sometimes negatively impacts his performance (Suharto, 2012). This phenomenon is the reason for researchers to see the quality of human resources in this case reliable institutional lecturers and is a very urgent need to be met, given the rapid changes in the environment. Moreover, coupled with globalization which is a tough challenge so as to face challenges, grabbing and filling opportunities it takes adequate capabilities shown through good work performance (Sudarwati, 2014). The purpose of this study looked at the extent of the influence between motivational variables, and competencies mediated by lecturer job satisfaction towards lecturer awards, or which variables partially dominantly affect lecturer achievement. Later this research as a material of information and consideration for gorontalo universities, especially in formulating policies to enhance lecturers' performance.

In line with this, the progress of an organization is reflected in its success in facing dynamics. Dynamics encourage new changes so that the organization can face competition and achieve goals through fulfilling job satisfaction based on achievement and meritocracy (Sulastyo, 2009). Unlike the theory, the dynamics of the organization at private universities in Gorontalo Province showed different things. It can be seen that there are still many lecturers who do not master the teaching field, have low attendance rates, do not have innovation and do not take the initiative to do effective teaching methods. The knowledge of lecturers about the courses is still low because the competence of lecturers is not following orientation quality, problem-solving abilities, planning abilities, teamwork abilities, and self-learning capacity.

Besides, not as much of lecturers capable of doing their main tasks and functions, nor analyse teaching problems and solve them. Lecturers' skills in preparing work planning are still a concern, including the ability to coordinate and communicate within teamwork effectively and the ability to carry out active learning processes both independently and in 
groups, all need to be built up. Various aspects make human resources satisfied and excel in their work activities. According to (Tohardi, 2008),there is an influence of competence and motivation on job satisfaction and achievement. (Robbins, 2007) states that having competence drives people to excel and meet job satisfaction in organizations. Furthermore, (Banham, 2005) assessed that there is a mutually influential relationship between competence, job satisfaction and achievement in an organization.

The competence variable has a dominant effect on performance and performance according to the observed variables, that is to say recruits, skills and motivation. Furthermore, research conducted by (Miah, 2018) shows that ability of work has a significant effect on performance and not significantly on the satisfaction of administrative staff at private-sector employees in Kuching, East Malaysia. Meanwhile, the capability theory introduced by (Terry, 2008) states that every human resource has competence. The ideal competence is supported by quality orientation, problem-solving skills, planning skills, teamwork and self-learning capacity. Every human being has potential because that potential is about improving and increasing the competence of human resources. Research conducted by (Laoryerd and Ikeda, 2007) shows that Competency, motivation, and recruitment have a main effect in increasing organizational departments on job satisfaction and terms of company performance. Whilst discipline does not show a significant influence, because the Japanese have been known for their work discipline culture.

According to (Rivai, 2007), the term of motivation is interpreted as an impulse that arises in a person consciously or unconsciously to act with a specific goal. The focus of motivation in an organization that refers to Herzberg's theories is commonly referred to as factors $\mathrm{X}$ and $\mathrm{Y}$, which include the provision of motivational compensation, improvement of workplace conditions, promotion of positions, work responsibilities and work itself.

Subsequent research conducted by (Valaei and Rezaei, 2016) examined the effect of competence on job satisfaction results, found that competence consisting of quality orientation, problem-solving ability and learning capacity has a significant effect on work achievement. According to (Robbins, 2007) theories about job satisfaction can be classified into two, as follows: (1) Equity Theory, Someone would feel fulfilled or dissatisfied whether or not he or she feels the existence of justice. Perceptions of equity or unfairness about someone's situation when comparing with other people in the same class, office or elsewhere. (2). Two Factor Theory, The principle of this theory is that job satisfaction and dissatisfaction are two different things.

This theory suggests that work characteristics can be divided into two categories, one of which is called dissatisfaction or hygiene factors. (Ehsan et al., 2012) research results show that compensation, work environment, promotion, responsibility and work itself have a significant influence in determining a person's success, motivation and satisfaction to excel their job. Also, research conducted by (Eren et al., 2013) stipulated that job satisfaction of personnel is assessed based on quality and service excellence, characteristics and an upstanding reputation. (Rivai, 2007) states that a person's overall work performance during a certain period in carrying out tasks in various aspects of quantity, quality, efficiency and effectiveness.

The discussion of previous research presented above became a reference and comparison of the research conducted. Therefore, this study looks at the interesting question about whether or not the lecturers' competence and motivation affecting lecturer achievement at private universities in Gorontalo Province. 
Maslow, (Tohardi, 2008) stated that motivation plays an important role in achieving organizational goals. Maslow recommends meeting the needs of motivation to increase job satisfaction and achievement. Herzberg advocated motivational expectations, and McClelland advocated achievement motivation according to job satisfaction. Rybnicek et al., 2019 addresses that motivation is the key to realizing individual HR achievers to produce job satisfaction. Therefore, it is interesting to look at the case at lecturers at private higher education institutions in Gorontalo.

\section{THEORETICAL REVIEW}

Organizations have a wide array of resources, such as "inputs," which can be converted in the form of goods or products for services. These include capital or money, technology or production process support, operating strategy methods, people, etc. Human transmission resources are the most valuable components of these various resources. A management system termed human resources management is required to plan, manage and control human resources. Management of human resources can be understood as a strategy.

(Nawawi, 2003) is a man who is able to produce a good or a good thing so that man is regarded as a source for making something. There are two elements of human resources, namely empowered resources and human potential. Human resources are referred to as potential, whereas people are called human resources resources potentials so that the human potential in the management of resources is the living organism potential in a day-to-day human resource.

This claims to support that which (Nuryanto, 2000) indicates that the potential value of the human resources should be empowered, used and utilized by people to create great advantages for prosperity and prosperity. Agree with the description, which (Simamora, 1995) that the potential of resource elements in three groups is human, financial and natural resource potential. The human resources play a major role in producing useful or economically valuable things among these three groups. Then (Siagian, 1995) affirmed that the human resources can be defined as the ability to generate output from processes that are derived from inputs to generate profit (benefit).

It takes a competency in competition in the current technological era, competence that belongs to the basic human characteristics that from real experience (visible from behavior) found to affect, or can be used to estimate (level) performance in the workplace or the ability to solve problems in a particular situation (Spencer, 1993) (Pfeffer et al., 2003). Moreover, scientists are looking at Spencer's theory, where skills can be divided into two categories: threshold skills and differential skills. Skills of thresholds are the main characteristics a person needs to do their job. But not a high-performance, medium-sized person. Although "differential skills" are factors which characterize people with high and low performance.

Based on definition of threshold competencies and differentian competencies means that humans can do a job easily because of their experience and skill, in the era of digitalization humans can also easily work and complete their work. Further development of the concept of threshold competencies, that humans are smart in getting the job done, because they have knowledge and experience. Knowledge is gained of course from learning. The more knowledge they have, the easier it will be to solve the problems at work. Of course, knowledge alone is not enough, humans are also given the sense to reason to reason well, humans with experience are able to make accurate conclusions. 
Similarly, the current era, when the industry has undergone changes to the 4th stage, where technological sophistication has taken over some human work that can make a job completed in a fast time. This is due to human knowledge that can make a tool or machine that can help them work. Of course, the development of machines known as artificial intelligence is very helpful to the work problems they face, this is also inseparable from the controversy of artificial intelligence when associated with the concept of differentian competencies, where low-performance humans can be eliminated by the presence of artificial intelligence. Of course, a series of competencies can not be separated from the development of technology, nowadays almost all elements of companies and organizations use digital technology as a tool that can help them. In other words, in this era when the person is not able to use existing technology then the person has not been competent even they are considered not to have enough skills in working. Technology openness can be an opportunity for a person to have high competitiveness. But on the other hand, this can certainly also be a threat to those who will be sidelined because of the ability of those who have not been able to master the existing technology.

\section{H1 : Competence has a significant influence directly on lecturer achievement. \\ $\boldsymbol{H 3}$ : Competence has a significant influence on lecturer achievement through mediation of job satisfaction.}

Every organization certainly has a goal to achieve. To achieve this goal, the role of the human being involved in it is very important. To move people to fit the desired organization, it must first be understood the motivation of human beings who work in the organization because it is this motivation that determines the behavior of the working people, or in other words behavior is the simplest reflection of motivation. In order for there to be alignment of maniacal behavior with the purpose of the company there should be a combination of their motivation and the request of the organization (Reksohadiprodjo, and Handoko, 1986).

The key word of the description is motivation which is defined as a person's personal circumstances that encourage the individual's desire to perform certain activities in order to achieve a goal. So the motivation in a person will realize a behavior directed at the goal of achieving the goal (Reksohadiprodjo and Handoko, 1986) but its existence can be felt through visible behavior. The activities a person performs are driven by the strength in the person. It is this driving force called motivation.

Another definition of motivation mentions it as a process that determines the choice between several alternatives to voluntary activities. Most of the behavior is seen as voluntary controlled activities, and the arena is motivated (Gibson et al., 1984).

From a work perspective, (Luthans, 1995) suggests that motivation is a process that starts from physiological or psychological deficiencies or a process that starts from a need that refers to behavior or a motivation aimed at achieving a goal or intensive. So the key word for understanding the motivation process is the relationship between needs, motivations and incentives.

The definitions given by experts to motivational terms vary, although the meaning is almost the same. This is due to various theories about motivation. Like, (Gibson et al., 1984) used the concept of motivation to explain differences in behavioral intensity, i.e. 
more intense behavior as a result of higher motivation levels and also to indicate the direction of action.

(Prawatya and Raharjo, 2012) Suggesting that organizations are human systems and activities that work together. In line with that, the organization is said to be a rational coordination of the activities of a number of people to achieve some common goals through the division of work and functions through a hierarchy of authorities and responsibilities. Also, (Suwanto, 2011) explains that motivation comes from the Latin movere which means the driving force of man to act, or an energy in the human being that causes man to act. From the word movere arises the sense of motivation that is the giving of motives, the giving of motives or things that cause encouragement. The motivation of people is basically motivated or encouraged to behave in a certain way that is perceived to lead to the acquisition of rewards or to achieve results, motivation starts from perceived needs and then leads to efforts to achieve goals or goals.

Furthermore (Lounsbury et al., 2003), developed a motivational theory known as hierarchy of needs as follows: physiology, safety and threats, environment or events, sense of belonging, social and love, self-esteem, the need for appreciation of others, selfactualization, the need to fulfill oneself by maximizing the use of abilities, skills and potentials. Maslow's theory assumes that people strive to meet more basic (physiological) needs before directing to behaviors that meet higher needs (self-realization).

The first factor of this theory is "motivators" which are factors related to positive feelings towards the work and related to the content of the work, so in the group of "motivators" include the nature of the work itself or recognition of the ability and performance of work both by colleagues and by the leader of the company. Opportunities to progress and responsibilities carried by the employee concerned. Motivators are intrinsic factors or derived from within the work itself. The second factor or "hygienis" are factors related to negative feelings towards the work and related to the environment of the work done. Hygienis factors include organizational policy, administration, technical supervision, salary, working conditions, personal relationships within the organization. Hygienis factors are extefactors rnal or "extrinsic" against the work itself.

H2: Motivation has a significant direct influence on lecturer achievement.

H4: Motivation has a significant influence on lecturer achievement through job satisfaction.

The attitude of a person towards his work is job satisfaction. A highly satisfied employee will have a positive attitude to his work. Conversely, a person who is unhappy with his work is unhappy with his/her work. The satisfaction of the job is closely related to the employee's pleasant and disagreeable emotional state in terms of his job. When the organization pays attention and meets all employees' needs, the employee has an interior sense of happiness and happiness in the workplace and at work. The higher the employment level, the more factors the work conforms to the wishes of the employee of the statisfaction.

Job satisfaction according to (Luthans, 2008) can be understood in three aspects. First, job fulfillment is a way of responding to working conditions. Second, work performance or results often determine satisfaction. Thirdly, satisfaction with employment is linked to other attitudes and belongs to all workers. According to (Mangkunegara, 2011) job satisfaction is a feeling that supports or does not support the employee who is related to his job or with his condition. (Koesmono, 2005) explain that job satisfaction can be defined as an individual's 
feelings and reactions to his work environment. (Koesmono, 2005) explained that Perceived quality at work is a pleasure or a favorable motivational statement that comes from the work or work experience assessment. According to (Hasibuan, 2013) job satisfaction is a pleasant emotional attitude and loves his job. This attitude is reflected by work morals, discipline and work performance. Job satisfaction is enjoyed in the work, outside the job and the combination of inside and outside the job. Based on some of the above opinions, it can be concluded that job satisfaction is the attitude and feelings of employees, employees or workers to the work they do, their work environment, rewards or rewards received and assessment of the results of their work. These feelings can be feelings of pleasure, displeasure, comfort or discomfort. It is also inseparable from the role of awards given by institutions to lecturers who have a good level of performance. This exercise can also trigger the lecturer to be satisfied in working.

Awards are more meaningful when the form used is rated higher by the recipient. An individual may highly assess rewards related to his or her work, such as educational opportunities, while another individual may rate high rewards related to personal and family life that can be shared withothers.

(Istijanto, 2006) an award is something given to an individual or group if they do something accomplished in a particular field. Awards are usually given in the form of medals, trophies, titles, certificates, plaques or ribbons. An award is sometimes accompanied by a prize in the form of money such as a Nobel prize for contributions to society and a Pulitzer prize for literature. Award or "Reward is a reward, gift, reward or reward that aims to make a person become more active in his efforts to improve or improven (Nugroho, 2006). On the other hand, According to (Nugroho, 2006) the main objective of the reward program is: Attracting people who have qualifications to join the organization or retain employees in order to keep coming to work and can employees (in this case lecturers) to achieve a high level of performance.

\section{H5: Job satisfaction has a significant influence on lecturer achievement.}

\section{METHODS}

This research is a causality study that aims to, test the influence of islamic advertising variables, and islamic brands on purchasing decisions and satisfaction. In addition, the research also aims to predict and develop theory. Looking at the form of models and the number of endogenous variables that are more than one, then the right analysis technique used is a model of structural equations (Structural Equation Modelling - SEM) based on variants or partial least square (PLS).

According to (Jogiyanto, 2011) PLS is a variant-based SEM analysis that can simultaneously perform measurement model testing as well as sktruktural model testing. The use of PLS-based SEM is the same as the use of multiple linear regressions, i.e. maximizing the variants described in endogenous latent variables (dependent variables) with additional analysis of data quality assessments based on the characteristics of the measurement model.

The use of PLS in this study is based on several considerations i.e. (1) PLS can be used to test the predictive effect of relationships between latent variables, (2) PLS does not require normal distributed data (indicators with category scale, ordinal, interval to ratio can 
be used on the same model), samples do not have to be large (Ghozali, 2011), and regression approach (path analysis) in variant-based PLS-SEM is more suitable for use than in covariance-based SEM such as AMOS and LISREL.

This research includes all lecturers that working in various universities in goronatalo's province. So far, the number of lecturers in Gorontalo province who have obtained certification is inaccurate. Therefore, this research used a non-probability category, with 100 respondents. As for the samples criteria in this study are lecturers who have obtained a professional certification and have worked in universities for at least 5 Years and sampling technique used is purposive sampling.

The data measurement using our five-point Likert scale asked respondents to show their response to their job satisfaction and how the rewards they earned from the college. The scales used in this study ranged from (1), strongly disagreeing; (2), disagree; (3),simply agree; (4), agree; and (5), strongly agreed. The criteria in this sample are they have obtained professional certification and have at least five years of work experience. Taking into account that the working period and professional certificate have been obtained, respondents have enough experience in their knowledge about their motivation and competence towards lecturer awards. When compared to respondents who have not obtained a professional certificate. Thus, makes it easier for researchers to obtain more reliable study results. This study also used four (4) variables, namely; competence; Motivation; lecturer achievement; and job ststisfaction as a mediation variable.

This research used structural equation modeling techniques (SEM) (Albright et al., 2009), which was applied to this study to empirically test the relationship of competence and motivation to lecturer achievement and mediation of variable job satisfaction, which is to see indirect influence. Using PLS software (Sarstedt et al., 2011), the study estimated Alpha Cronbach (CA), total item correlation, and confirmatori factor analysis to test reliability, convergent validity and discriminant validity for each concept framework construct (Jöreskog, 2005).

\section{RESULTS}

The external model is a model which specifies the relationship between latent variables and their indicators or the external model determines how each indicator has to do with its latent variable. The external model is interpreted by considering a number of things, such as converging value, discriminating validity, composite reliability, average extract variance (AVE) and alpha cronbach. The PLS Algorithm model is presented in the figure 1.

For each latent variable, the convergent value measures the size of the loading factor. It is highly recommended to load over the 0.70 factor, but loading up to the 0.50 factor is tolerable while the model is still in the development phase. The results of the full loading indicator value are presented in the table 1. 


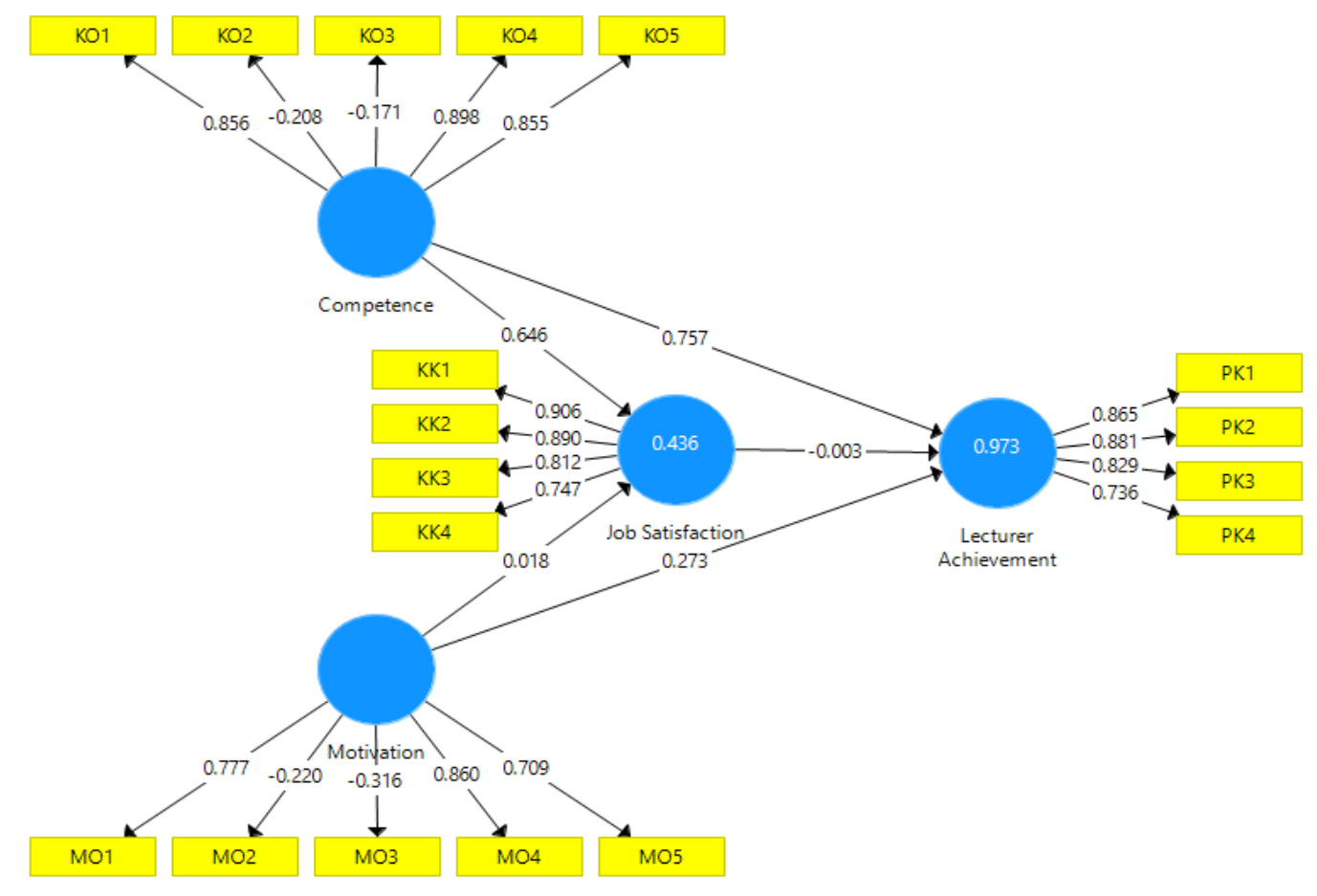

Figure 1. PLS Algorithm Model 1

Table 1. Outer Loadings Value 1

\begin{tabular}{lllll}
\hline Variables/Indicators & Competency & Motivation & Job Satisfaction & $\begin{array}{c}\text { Lecturer } \\
\text { Achievement }\end{array}$ \\
\hline C1 & 0,856 & & & \\
C2 & $-0,208$ & & & \\
C3 & $-0,171$ & & \\
C4 & 0,898 & & & \\
C5 & 0,855 & 0,777 & & \\
M1 & & $-0,220$ & & \\
M2 & $-0,316$ & & \\
M3 & 0,860 & & \\
M4 & 0,709 & & \\
M5 & & 0,906 & \\
JS1 & & 0,890 & \\
JS2 & & 0,812 & 0,865 \\
JS3 & & 0,747 & 0,829 \\
JS4 & & & 0,736 \\
LA1 & & & \\
LA2 & & & & \\
LA3 & & & \\
LA4 & & & & \\
\hline
\end{tabular}

Table 1 shows that the competence contract, the outer loadings value on indicator $\mathrm{C} 1$ is $0.856, \mathrm{C} 2$ is $-0.208, \mathrm{C} 3$ is $-0.171, \mathrm{C} 4$ is 0.898 , and $\mathrm{C} 5$ is 0.855 . Motivation contract, outer loadings on the MO1 indicator are $0.777, \mathrm{MO} 2$ is $-0.220, \mathrm{MO} 3$ is $-0.316, \mathrm{MO} 4$ is 
0.860 and MO5 is -0.709 . Job Satisfaction contract, outer loadings value on JS1 indicatorof 0.906, JS2 of 0.890 , JS3 of 0.812 and JS4 of 0.747. Konstrak Lecturer Achievement, outer loadings on indicator LA1 of 0.865 , LA2 of 0.881 LA3 of 0.829 and LA4 of 0.736 . From the results of the validity convergence above, there are still outer loadings values that are $<$ 0.6 namely $\mathrm{C} 2, \mathrm{C} 3, \mathrm{MO} 2$, and $\mathrm{MO} 3$, where the indicators are not valid then removed from the model. While the indicator with outer loadings value of 0.6 is said to be valid, then the indicator is valid as a contract gauge. Then a second algorithm test is conducted.

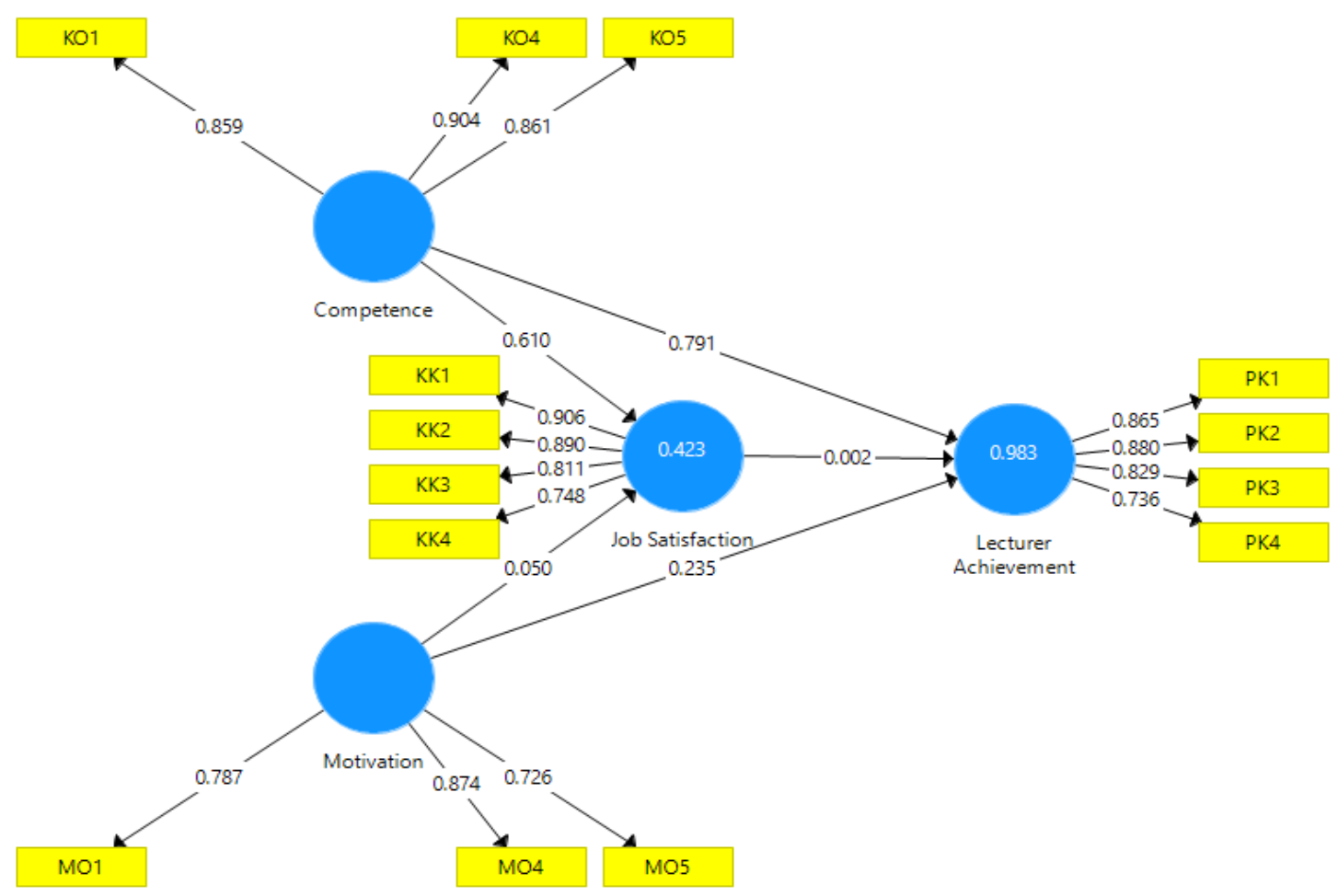

Figure 1. PLS Algorithm Model 1

Table 2. Outer Loadings Value To 2

\begin{tabular}{lllll}
\hline Variables/Indocators & Competence & Motivation & Job Satisfaction & $\begin{array}{c}\text { Lecturer } \\
\text { Achievement }\end{array}$ \\
\hline C1 & 0,859 & & & \\
C4 & 0,904 & & & \\
C5 & 0,861 & 0,787 & & \\
M1 & & 0,874 & & \\
M4 & 0,726 & & \\
M5 & & 0,906 & \\
JS1 & & 0,890 & \\
JS2 & & 0,811 & \\
JS3 & & 0,748 & \\
JS4 & & & \\
LA1 & & & & \\
& & & & \\
\hline
\end{tabular}




\begin{tabular}{lr} 
LA2 & 0,880 \\
LA3 & 0,829 \\
LA4 & 0,736 \\
\hline
\end{tabular}

Table 2 shows that all indicators obtain a loading value with the value outer loadings $>0.6$ is said to be valid, then all indicators are valid as a gauge of the contract. A high composite reliability value indicates the consistency of each indicator in a latent variable to measure that variable. The composite reliability value criterion of 0.7 indicates that the variable has good internal consistency. The full composite realibility value is presented in the table 3 .

Table 3. Composite Reliability Value

\begin{tabular}{cc}
\hline Variables & Composite Reliability \\
\hline Competence & 0,907 \\
Motivation & 0,839 \\
Job Satisfaction & 0,906 \\
Lecturer Achievement & 0,898 \\
\hline
\end{tabular}

Table 3 shows that the value of composite reliability contract Competence 0.907, Motivation 0.839, Job Satisfaction 0.906 and Lecturer Achievement 0.898. The four contracts composite reliability value of 0.70 is said to have good internal consistency. The AVE value indicates the variance value of each indicator in the contract that can be captured by the variable more than the variance resulting from measurement errors. Expected AVE value $>0.5$. AVE value of Competence contract 0.766, Motivation 0.637, Job Satisfaction 0.707 and Lecturer Achievement 0.688. More results are presented in the table 4 .

Table 4. Average Variance Extracted Value (AVE)

\begin{tabular}{cc}
\hline Variables & Average Variance Extracted (AVE) \\
\hline Competence & 0,766 \\
Motivation & 0,637 \\
Job Satisfaction & 0,707 \\
Lecturer Achievement & 0,688 \\
\hline
\end{tabular}

At this stage, the researchers then performed ujireliability which is reinforced by cronbach's alpha value. Cronbach's alpha reliability test limitation $>0.7$. Cronbach's alpha value obtained by Competence contract 0.847 , Motivation 0.720 , Job Satisfaction 0.872 and Lecturer Achievement 0.848 . The results of the full Cronbach's alpha value are presented in the table 5 .

Table 5. Cronbach's Alpha Value

\begin{tabular}{cc}
\hline Variables & Cronbach's Alpha \\
\hline Competence & 0,847 \\
Motivation & 0,729 \\
Job Satisfaction & 0,872 \\
Lecturer Achievement & 0,848 \\
\hline
\end{tabular}


To test the structural model is done by looking at the value of R2 which is a Test of Goodness of the fit. Job Satisfaction contract obtained R2 value of 0.423 which can be interpreted that the variant on Job Satisfaction can be explained by competence and motivation contract of $42.3 \%$ while the remaining $57.7 \%(100 \%-42.3 \%)$ described by other variables outside the research. Similarly, lecturer achievement contract with R2 value obtained by 0.983 or $98.3 \%$. This value indicates that the variation in lecturer achievement contract can be explained by competence, motivation and job satisfaction contracts of $98.3 \%$ while the remaining $1.7 \%(100 \%-98.3 \%)$ described by other variables that were not studied. The results of the full R-square values are presented in the table 6 .

Table 6. R-Square Value

\begin{tabular}{ll}
\hline & R Square \\
\hline Job Satisfaction & 0,423 \\
Lecturer Achievement & 0,983 \\
\hline
\end{tabular}

The next test is to look at the significance of the influence between independent contracts on dependents and answer what has been hypothesized. Testing with a significance level of $5 \%$ if the t-statistic value $>1.96$ then the zero $(\mathrm{H} 0)$ hypothesis is rejected. The $\mathrm{t}-$ statistical value of the coefficient of influence of latent contracts is obtained from PLS Bootstrapping. Pls Bootstrapping Model results are presented in the figure 2.

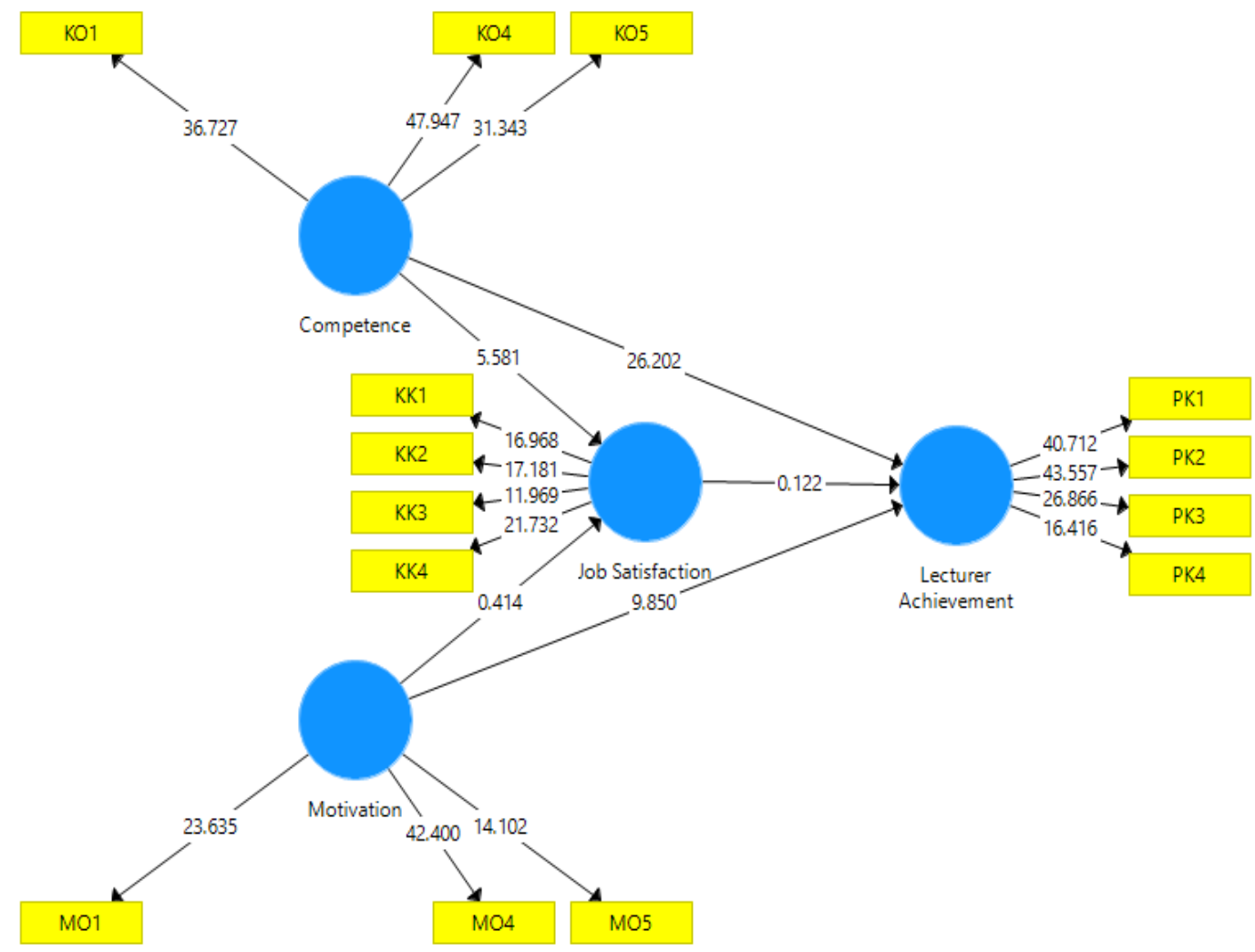

Figure 2. PLS Bootstraping Model 
The value of the parameter coefficient can be seen in the value (original sample) and the value of significance t-statistics can be seen in the table 7 .

Table 7. Coefficient Values (Original Sample), Standard Error and T-Statistics

\begin{tabular}{lccccc}
\hline & $\begin{array}{c}\text { Original } \\
\text { Sample } \\
(\mathbf{O})\end{array}$ & $\begin{array}{c}\text { Sample } \\
\text { Mean } \\
(\mathbf{M})\end{array}$ & $\begin{array}{c}\text { Standard } \\
\text { Deviation } \\
(\text { STDEV) }\end{array}$ & $\begin{array}{c}\text { T Statistics } \\
(|\mathbf{O S T D E V}|)\end{array}$ & $\begin{array}{c}\mathbf{P} \\
\text { Values }\end{array}$ \\
\hline Competence -> Job Satisfaction & 0,610 & 0,613 & 0,109 & 5,581 & 0,000 \\
Competence -> Lecturer Achievement & 0,791 & 0,791 & 0,030 & 26,202 & 0,000 \\
Job Satisfaction -> Lecturer Achievement & 0,002 & 0,001 & 0,020 & 0,122 & 0,903 \\
Motivation -> Job Satisfaction & 0,050 & 0,054 & 0,121 & 0,414 & 0,679 \\
Motivation -> Lecturer Achievement & 0,235 & 0,236 & 0,024 & 9,850 & 0,000 \\
\hline
\end{tabular}

H1 : The coefficient of competence's influence on Job Satisfaction is 0.610, the standard error value is 0.109 and the $t$-statistical value is 5,581. Because the t-statistical value is 5,581 > 1.96 then receive $\mathrm{H} 0$. This proves that competence has a significant positive effect on job satisfaction.

$\mathrm{H} 2$ : Motivation coefficient of influence on Job Satisfaction of 0.050, standard error of 0.121 and $t$-statistical value of 0.414 . Because the $t$-statistical value is $0.414<1.96$ then reject $\mathrm{H} 0$. This can be interpreted that motivation does not significantly positively affect Job Satisfaction.

H3 : The coefficient of effect of Job Satisfaction on Lecturer Achievement is 0.002, standard error is 0.020 and t-statistical value is 0.122 . Because the $t$-statistical value is $0.122<1.96$ then reject H0. It can be stated that Job Satisfaction does not significantly affect lecturer achievement.

H4 : Coefficient of competence influence on Lecturer Achievement of 0.791, standard error 0.030 and t-statistical value of 26.202. Because the t-statistical value is $26.202>1.96$ then receive H0. It can be stated that Competence significantly affects Lecturer Achievement.

H5 : Motivation coefficient of influence on Lecturer Achievement of 0.235, standard error 0.024 and t-statistical value of 9,850 . Because the t-statistical value is $9850>1.96$ then receive H0. It can be stated that Motivation significantly affects Lecturer Achievement.

Table 8. Indirect Effect

\begin{tabular}{lccccc}
\hline & $\begin{array}{c}\text { Original } \\
\text { Sample } \\
(\mathbf{O})\end{array}$ & $\begin{array}{c}\text { Sample } \\
\text { Mean (M) }\end{array}$ & $\begin{array}{c}\text { Standard } \\
\text { Deviation } \\
\text { (STDEV) }\end{array}$ & $\begin{array}{c}\text { T Statistics } \\
\text { (| }\end{array}$ & $\begin{array}{c}\text { P/STDEV|) } \\
\text { Values }\end{array}$ \\
\hline $\begin{array}{l}\text { Competence -> Job Satisfaction -> } \\
\text { Lecturer Achievement }\end{array}$ & 0,001 & 0,001 & 0,012 & 0,121 & $\mathbf{0 , 9 0 3}$ \\
$\begin{array}{l}\text { Motivation -> Job Satisfaction -> } \\
\text { Lecturer Achievement }\end{array}$ & 0,000 & $-0,001$ & 0,003 & 0,045 & $\mathbf{0 , 9 6 4}$ \\
\hline
\end{tabular}

The table 8 shows that:

The effect of Competence on Lecturer Achievement through Job Satisfaction is 0.001, standard error 0.012 and t-statistical value is 0.121 . Because the t-statistical value is 1,121 
$<1.96$ then reject H0. It can be stated that Competence has no significant effect on Lecturer Achievement through Job Satisfaction.

The effect of motivasi on Lecturer Achievement through Job Satisfaction of 0.000, standard error 0.003 and $t$-statistical value of 0.045 . Because the $t$-statistical value is 0.045 $<1.96$ then reject H0. It can be stated that motivation has no significant effect on Lecturer Achievement through Job Satisfaction.

\section{CONCLUSION}

The results of the analysis with smart-pls program application to hypothesis testing through the research model, and the discussion of the results provide conclusions: competence has a significant influence on lecturer achievement both directly and mediated from the variable of job satisfaction. While motivational variables do not have a significant influence on lecturer achievement either directly or mediation of job satisfaction, this is because there are several measurement indicators that are rated low by respondents, causing the lack of motivation variables to get a positive response as one of the benchmarks of job satisfaction and appreciation. However, on the other hand, motivation exerts a significant influence on rewards through job satisfaction when tested for indirect influence. The results of this study are also in line with research conducted by (Juniari et al., 2015), where motivation does not significantly affect the award. In his study, motivation was seen from five levels of needs, namely physiological, security, social, reward, and self-actualization. Social needs, security, and physiological needs become the highest gauge of employee motivation, especially the family atmosphere in work, transportation facilities to the workplace and the granting of attendance money and performance allowances have an impact on employee performance. Further research conducted by (Hanafi and Yohana, 2017), where the results showed that the work environment dominates more in relation to performance levels. This study also used the variable of job satisfaction as a mediation variable between motivation and work environment to employee performance.

Based on the research that has been done, the author gives some suggestions including: first, can encourage and trigger the conduct of subsequent researches in the field of human resource management by using other variable variables that have not been included in this study, such as leadership, work climate and work facilities. Second, it is expected to increase the number of respondents and can use the interview method in obtaining valid data and describing the actual condition, because this study is still simple in testing the relationship of related variables.

\section{REFERENCES}

Albright, Jeremy J.; Park, H.M. (2009). Albright, J. Indiana University. Retrieved from http://hdl.handle.net/2022/19736.

Banham, J. (2005). Development of Human Resource Management. New York.: Prentice Hall Int Ed.

Ehsan Malik, M., Qaiser Danish, R., and Munir, Y. (2012). The Impact of Pay and Promotion on Job Satisfaction: Evidence from Higher Education Institutes of Pakistan. American Journal of Economics. https://doi.org/10.5923/j.economics.20120001.02. 
Eren, S. S., Eren, M. Ş., Ayas, N., and Hacioglu, G. (2013). The Effect of Service Orientation on Financial Performance: The Mediating Role of Job Satisfaction and Customer Satisfaction. Procedia - Social and Behavioral Sciences. https://doi.org/10.1016/j.sbspro.2013.10.537.

Hanafi, B. D., and Yohana, C. (2017). Influence of Motivation, And Work Environment, On Employee Performance, With Job Satisfaction As Mediation Variable At Pt Bni Lifeinsurance. Journal of Economic and Business Education (JPEB), 5(1), 73-89. https://doi.org/10.21009/jpeb.005.1.6.

Jöreskog,K. (n.d.).

Juniari, N. K. E., Riana, I. G., and Subudi, M. (2015). The effect of motivation on work satisfaction and employee performance of government employees at STP Nusa Dua Bali. E-Journal of Economics and Business udayana University, 4(11), 823-840.

Competency, P., Dan, K., Work, D., Performance, T., Agency, P., and Region, P. (2019). The influence of competence, compensation and work discipline on the performance of employees of the regional revenue agency makassarcity. 2.

Lounsbury, J. W., Sundstrom, E., Loveland, J. L., and Gibson, L. W. (2003). Broad versus narrow personality traits in predicting academic performance of adolescents. Learning and Individual Differences, 14(1), 65-75.

Miah, M. (2018). The impact of employee job satisfaction towards organizational performance: A study of private sector employees in Kuching, East Malaysia. International Journal of Scientific and Research Publications, 8(12). https://doi.org/http://dx.doi.org/10.29322/IJSRP.8.12.2018.p8437.

Pramukti Andika. (2019). Pengaruh Motivasi, Kompetensi, Dan Pengembangan Karir Terhadap Komitmen Organisasi Dan Kinerja Pegawai. Retrieved from DOI: https://doi.org/10.37541/eq.v1i1.270.

Prawatya, D. A., \& Raharjo, S. T. (2012). The Influence of Organizational Discipline and Culture on The Performance of Employees of Eucalyp Oil Plant (Pmkp) In Krai Purwodadi. Diponegoro Journal of Management, 1(1), 323-331.

Rivai, V. (2007). Performance Appraisal. Jakarta: PT Raja Grafindo Persada.

Robbins, S. (2007). Organizational Behavior (10th ed.). Jakarta: Publisher PT. Brilliant Jaya Tigers.

Rybnicek, R., Bergner, S., and Gutschelhofer, A. (2019). How individuals need influence motivation effects: a neuroscientific study on McClelland's need theory. Review of Managerial Science. https://doi.org/10.1007/s11846-017-0252-1.

Sarstedt, M., Henseler, J., and Ringle, C.M. (2011). Multigroup analysis in partial least squares (PLS) path modeling: Alternative methods and empirical results. Advances in International Marketing, 22(June 2014), 195-218. https://doi.org/10.1108/S14747979(2011)0000022012.

Sudarwati, A. (2014). The Influence of Competence And Appreciation On The Work Motivation of Employees of Pt Kai At Sragen Station. Paradigm Journal of Batik Islamic University of Surakarta, 12(01), 116413.

Suharto, A. A. (2012). Effect of Quality of Human Resources, KOmitmen And MOtivasi On Employee Performance In kediri district inspectorate. Management Science, 3,67-79.

Suprianto, S., Basalamah, S., and Arifin, Z. (2019). Effect of Remuneration, Work Culture, and Competence on The Performance of Employees of Pratama Makassar Utara Tax 
Service Office. PARADOX: Journal of Economic Sciences, 2(3), 89-95. Suwanto,H. (2011).

Terry, G. (2008). Human Resource Management. In Human Resource Management. Ohio: McGraw Will.

Tohardi, A. (2008). Practical Understanding of HR Management. Bandung: Publisher of University of Tanjungpura, Mandar Maju.

Valaei, N., and Rezaei, S. (2016). Job satisfaction and organizational commitment. Management Research Review. https://doi.org/10.1108/mrr-09-2015-0216. 